Available online at: https://proceeding.researchsynergypress.com/index.php/rsfconferenceseries1

RSF Conference Series: Business, Management and Social Sciences

e-ISSN 2807-5803/ p-ISSN 2807-6699

Volume 1 Number 1 (2021): 30-35

\title{
Factors Contributing To Financial Literacy Level Among Youth
}

\author{
Hazlaili Binti Hashim1, Andy Lim Yee Chee², Yeo Sook Fern³, Anushia Chelvarayan4, \\ Khairol Nizat Bin Lajis ${ }^{5}$ \\ 1,2,3,4 Faculty of Business, Multimedia University, Malaysia \\ ${ }^{5}$ Faculty of Information Science \& Technology, Multimedia University, Malaysia
}

\begin{abstract}
The number of bankruptcy cases registered from 2017 to April 2021, according to the Malaysian Insolvency Department, is 58,065. Bankruptcy cases involving people under the age of 34 accounted for 24.28 percent of all filings. The inability to pay personal loans, instalment purchases, and credit card debt led to the majority of bankruptcy cases. This is alarming because it suggests that young Malaysians are still unaware of their financial situation. As a result, the goal of this research is to investigate the level of financial literacy among youth, as well as the relationship between financial knowledge, financial behaviour, financial attitude, and familial influences on financial literacy. A non-probability convenience sampling method was used to gather information from 181 respondents. The findings of the study show that financial knowledge $(\mathrm{p}=0.000)$, financial behaviour $(\mathrm{p}=0.000)$, and family influence $(\mathrm{p}=0.000)$ are significantly associated with financial literacy, the dependent variable in this study, with the exception of financial attitude $(\mathrm{p}=0.418)$. The sample size is among the limitation of this study which it does not represent the population of youth in Malaysia. The conclusions of this study have significant consequences for a variety of stakeholders, including university students, universities, students' parents, government, and future researchers. The factors that influence financial literacy among youth were investigated in this study, and several significant factors were revealed. This will also add to the supports of the agenda in the National Strategy for Financial Literacy 2019 to 2023.
\end{abstract}

Keywords: Financial Literacy; Knowledge; Behaviour; Attitude; Youth

This is an open access article under the CC-BY-NC license

\section{INTRODUCTION}

bankruptcy cases registered from 2017 until April 2021 is 58,065. People below the age of 34 made up $24.28 \%$ of the bankruptcy cases. Most of the bankruptcy cases were mostly due to the inability to sustain debt made of personal loans, instalment purchases and credit card debt. This is concerning because it indicates that young Malaysians still lack financial awareness. The National Financial Educators Council defines financial literacy as the capacity to successfully manage financial resources for long-term financial security. In addition, the economic ramifications of the Covid-19 pandemic have raised the alarm about the need to enhance financial literacy in order to decrease young bankruptcies and produce potential entrepreneurs with financial discipline who can withstand difficult market situations.

According to the results of the 2020 RinggitPlus Financial Literacy Survey, Malaysians' personal financial habits have not improved from the previous year (2019). Malaysians' failure to plan for retirement continues to be a source of concern. Despite a minor increase in the percentage of Malaysians who save on a monthly basis, and 76 percent professing to be in charge of their finances, this is the case.

Corresponding author

Hazlaili Binti Hashim, hazlaili.hashim@mmu.edu.my; Andy Lim Yee Chee, 21181301899@student.mmu.edu.my; Yeo Sook Fern, yeo.sook.fern@mmu.edu.my; Anushia Chelvarayan, anushia.chelvarayan@mmu.edu.my; Khairol Nizat Bin Lajis, khairol.lajis@mmu.edu.my 
The survey also demonstrated the impact of Covid-19 on Malaysians' purchasing habits, with the most notable trends being an increased preference for cashless payments and online purchases following the implementation of Covid-19 in the country. It has concluded in the survey that the financial literacy among youths/millennials were worse than the national average. If depending surviving only on savings, almost $26 \%$ of the youths cannot survive beyond one month, almost $60 \%$ cannot survive beyond three months, $47 \%$ of them agreed that they were spending exactly or more than what they earn and almost $50 \%$ of them have not started retirement planning.

Hence, the objective of this study is to look into the level of financial literacy among young people/millennials, as well as the relationship between financial knowledge, financial behaviour, financial attitude, and family influence on financial literacy.

\section{LITERATURE REVIEW}

Financial literacy includes an understanding of basic financial concepts and the ability to work with numbers in a financial context. The ultimately goal is to ensure that consumers can handle their financial matters solely and react properly to news and events that may influence their financial well-being (Morgan and Trinh, 2017). The definition conceptualized by Organization for Economic Co-operation and Development (OECD) is a widely acknowledged definition. Financial literacy refers to the knowledge and understanding of financial concepts and risks, as well as the skills, motivation, and confidence to apply that knowledge and understanding in order to make effective decisions in a variety of financial contexts, improve individual and societal financial well-being, and enable economic participation (OECD, 2014). OECD concentrates on the three essential basic measurements of financial literacy, namely financial knowledge, behaviour, and attitude (OECD-INFE, 2011).

Financial knowledge is a set of financial concepts and procedures needed in order to understand and solve financial matters (Alvare and Gonzalez, 2017). Lack of financial knowledge is a common issue in both developed and developing countries. Less financially literate individuals will face some problems in managing their finances efficiently, particularly in this modern society which require everyone to be well equipped with the ability to make sophisticated financial decisions (Lusardi and Mitchell, 2013).

Financial behaviour refers to the ability to recognize and comprehend the entire effects of financial decisions on one's situation, as well as the ability to make the best decisions possible regarding cash management, precautions, and budgeting opportunities (Tezel, 2015). In simple words, financial behaviour is the process of making financial management, practices and decisions.

Financial attitude involves assessing how an individual approaches financial matters (Kadoya and Khan, 2017). Previous research has found a link between young people's financial attitudes and their financial literacy (Kasman, Heuberger, and Hammond, 2018). Students' financial attitudes toward money are positively associated to their degrees of financial literacy (Soroshian and Teck, 2014). Financial literacy among youths can be framed by an attitude towards money. In order to achieve preferable degree of financial literacy and increase financial knowledge, the positive attitudes of students towards finance as well as money are necessary because they can influence the students' behaviour.

Family influence is always considered as one of the determinants of financial literacy among youth. The financial behaviour of one's family, such as spending, financial management, and payment, might impact the behaviour of other family members who live together (Thomas and Subhashree, 2020). 


\section{RESEARCH METHOD}

This study examines the relationship between financial knowledge, financial behaviour, financial attitude, and family influence on financial literacy among youth using the life cycle theory, which defines an individual's spending and saving behaviours. This idea can be used to show how people behave when it comes to money (Modigliani, 1975). Besides, social learning theory also states that in this society, individuals learn from others by observing and modelling their behaviour and actions. By using this theory, it provides a better understanding of how family, peer, and third parties can affect an individual's financial literacy (Bandura and Walters, 1977). The research framework was developed for this study using the findings obtained from the literature review. In order to investigate the significant relationship between the independent factors and the level of financial literacy among youth, four hypotheses were constructed for this study.

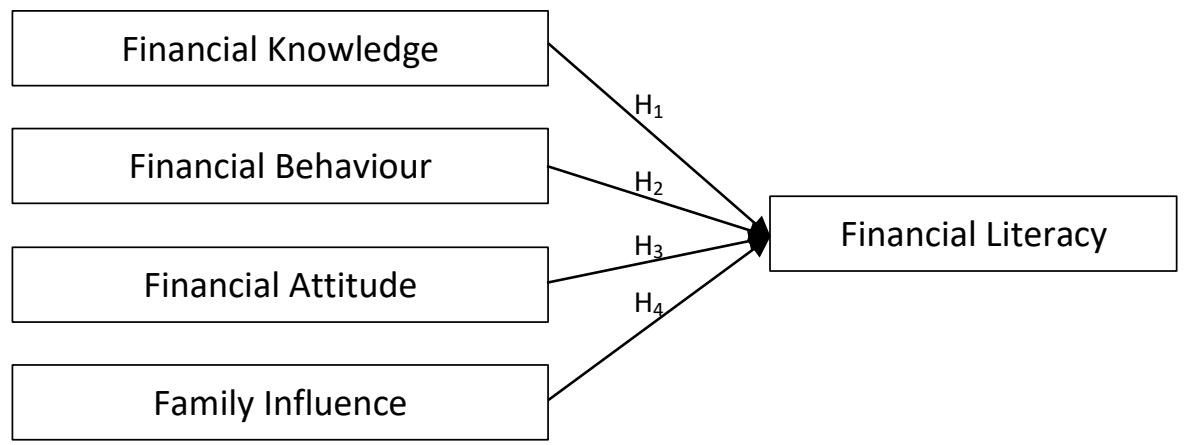

Figure 1: Research Framework

The correlational research technique was used in this study. The primary respondents for the study were selected using a non-probability convenience sampling technique among students. The primary objective of the convenience sample is to gather the knowledge of respondents that is readily available to the researcher. This study involved students from Multimedia University (MMU), Malaysia. Data collection was carried out from January to March 2021 using an online survey platform. In this study, data was gathered by questionnaires adopted from previous studies. Financial knowledge (Marsh, 2016), financial behaviour (Ahmad, Simun and Masuod, 2014), financial attitude (Rajna, Ezat, Aljunid and Moshiri, 2011), family influence (Jorgensen, 2007) and financial literacy (Juan, 2013). A Likert scale of 1 to 5 was employed in the surveys. Number one implies strongly disagree, while a value of five means strongly agrees.

\section{FINDINGS AND DISCUSSION}

A total of 181 respondents participated in the study. The table below illustrates the summary of all the socio-demographic data of the respondents.

Table 1: Respondents Profile

\begin{tabular}{|c|c|c|c|}
\hline Demographics & Elements & Frequency (N) & Percentage (\%) \\
\hline \multirow{3}{*}{ Gender } & Male & 67 & 37.0 \\
\cline { 2 - 4 } & Female & 114 & 63.0 \\
\hline \multirow{6}{*}{ Age } & 20 or below & 109 & 60.2 \\
\cline { 2 - 4 } & $21-25$ & 68 & 37.6 \\
\cline { 2 - 4 } & $26-30$ & 3 & 1.7 \\
\cline { 2 - 4 } & $31-35$ & 1 & 0.6 \\
\hline
\end{tabular}


RSF Conference Series: Business, Management and Social Sciences, Vol. 1 (1), 30-35

Factors Contributing To Financial Literacy Level Among Youth

Hazlaili Binti Hashim, Andy Lim Yee Chee, Yeo Sook Fern, Anushia Chelvarayan, Khairol Nizat Bin Lajis

\begin{tabular}{|c|c|c|c|}
\hline \multirow{4}{*}{ Race } & Malay & 22 & 12.2 \\
\cline { 2 - 4 } & Chinese & 135 & 74.6 \\
\cline { 2 - 4 } & Indian & 19 & 10.5 \\
\cline { 2 - 4 } & Others & 5 & 2.8 \\
\hline Education Level & Diploma & 48 & 26.5 \\
\cline { 2 - 4 } & Foundation & 8 & 4.4 \\
\cline { 2 - 4 } & Degree & 123 & 68.0 \\
\cline { 2 - 4 } & Postgraduate & 2 & 1.1 \\
\hline Course of Study & Business & 67 & 37.0 \\
\cline { 2 - 4 } & Law & 72 & 39.8 \\
\cline { 2 - 4 } & Information Technology & 42 & 23.2 \\
\hline Monthly Income & Less than RM1,000 & 117 & 64.6 \\
\cline { 2 - 4 } & RM1,000 - RM1,499 & 25 & 13.8 \\
\cline { 2 - 4 } & RM1,500 - RM1,999 & 15 & 8.3 \\
\cline { 2 - 4 } & RM2,000 - RM2,499 & 5 & 10.5 \\
\cline { 2 - 4 } & RM2,500 or above & 19 & \\
\hline
\end{tabular}

Since the independent variables and dependent variables are measured using a 5-point Likert scale, financial attitude achieves the highest mean, which is 3.7646. It explains that the majority of the respondents have a positive attitude towards financial literacy followed by family influence (mean=3.516), financial behaviour (mean=3.4354), and financial knowledge (mean=2.9715), which is the lowest mean value out of these four variables. It means that most respondents have insufficient knowledge of finances. While the dependent variable, financial literacy, with a mean of 3.2652, reveals that the level of financial literacy among university students in Multimedia University is at the moderate level.

Table 2: Mean \& Reliability Test Analysis

\begin{tabular}{|c|c|c|c|}
\hline \multicolumn{2}{|c|}{ Variables } & Mean & Cronbach's Alpha \\
\hline DV & Financial Knowledge & 2.9715 & 0.881 \\
\hline IV1 & Financial Behaviour & 3.4354 & 0.783 \\
\hline IV2 & Financial Attitude & 3.7646 & 0.773 \\
\hline IV3 & Family Influence & 3.5166 & 0.864 \\
\hline IV4 & Financial Literacy & 3.2652 & 0.817 \\
\hline
\end{tabular}

The Cronbach's Alpha values measure the reliability of the variables. The value is greater than 0.70 , which are considered consistent and reliable. Among these variables, financial knowledge achieves the highest Cronbach's Alpha value of 0.881 , followed by family influence (0.864), financial literacy (0.817), financial behaviour (0.783) and financial attitude (0.773) receives the lowest value.

The coefficient is the most crucial aspect of the analysis since it answers the proposed hypotheses about whether the independent factors and dependent variables have a significant relationship. All other independent factors, namely financial knowledge $(p=0.000)$, financial behaviour $(p=0.000)$, and family influence $(p=0.000)$, are significantly associated with financial literacy, the dependent variable in this study, with the exception of financial attitude $(p=0.418)$. 
Table 3: Hypothesis Test Result

\begin{tabular}{|c|l|c|c|c|c|c|c|}
\hline \multicolumn{2}{|c|}{ Model } & \multicolumn{2}{|c|}{$\begin{array}{c}\text { Unstandardized } \\
\text { Coefficients }\end{array}$} & $\begin{array}{c}\text { Standardized } \\
\text { Coefficients }\end{array}$ & t & Sig. & Result \\
\cline { 3 - 7 } \multicolumn{2}{|c|}{ B } & Std. Error & Beta & & \\
\hline & (Constant) & 0.235 & 0.214 & & 1.098 & 0.274 & \\
\hline H1 & $\begin{array}{l}\text { Financial } \\
\text { Knowledge }\end{array}$ & 0.447 & 0.060 & 0.427 & 7.506 & 0.000 & Accepted \\
\hline H2 & $\begin{array}{l}\text { Financial } \\
\text { Behaviour }\end{array}$ & 0.350 & 0.062 & 0.350 & 5.622 & 0.000 & Accepted \\
\hline H3 & $\begin{array}{l}\text { Financial } \\
\text { Attitude }\end{array}$ & -0.053 & 0.066 & -0.049 & - & 0.418 & Rejected \\
\hline H4 & $\begin{array}{l}\text { Family } \\
\text { Influence }\end{array}$ & 0.199 & 0.050 & 0.224 & 3.987 & 0.000 & Accepted \\
\hline
\end{tabular}

\section{CONCLUSION AND FURTHER RESEARCH}

The findings derived from this research provide some important implications for many parties, including university students, universities, parents of the students, policymakers and governors, and future researchers. This research has examined the factors that have a significant and insignificant relationship to the level of financial literacy among youth and identified several important factors which have an impact on financial literacy. Not only that, but it also considered the overall level of financial literacy among youth as a student. Thus, university students will receive the greatest benefits from this research. This research found that the financial literacy among them is at a moderate level. In order to elevate financial literacy level to become better, they can realize it by developing a positive financial behaviour and intensifying the financial knowledge, both are proven as the most effective way to ameliorate financial literacy. In addition, the university, as a tertiary education provider, is responsible for cultivating the future human capital with proper financial skills and abilities to assist in stimulating the economic growth and development of Malaysia and achieving the vision to be a developed country in 2025 eventually. Universities can use these findings as reference and design relevant financial programmes, curriculum, activities, courses, talks, etc. and offer to their students in order to enhance their financial literacy. In addition to the above, the findings of this research are useful to future researchers who are interested in this area and are going to carry out their own researches soon because they can gain a deeper understanding and new insights from this research. However, there is some limitation in this research. The sample size is considered small, and it does not represent Malaysia's youth population. Furthermore, due to the researchers' restricted time, the study's focus is only on MMU students. Because the financial literacy study has been thoroughly developed, it is advised that the research be expanded to cover all of Malaysia so that more inputs are available in keeping with the National Strategy for Financial Literacy 2019-2023 which aims to educate, inform, and support Malaysians in good financial management especially in understanding financing tools and knowledge they need to reach their financial goals, manage their debts, and avoid financial frauds.

\section{REFERENCES}

Ahmad, Z., Simun, M., \& Masuod, M. S. (2014). Determinants of financial behaviours among Malaysians. Indonesian Capital Market Review.

Álvarez, A. B. V., \& González, J. R. V. (2017). Financial Literacy: Gaps Found Between Mexican Public 
and Private, Middle, and High-School Students. In Handbook of Research on Driving STEM Learning With Educational Technologies (pp. 80-106). IGI Global.

Bandura, A., \& Walters, R. H. (1977). Social learning theory (Vol. 1). Englewood Cliffs, NJ: Prenticehall.

Jorgensen, B. L. (2007). Financial literacy of college students: Parental and peer influences (Doctoral dissertation, Virginia Tech

Juan, W. (2013). Saving behaviour among Chinese students. Center for Online Writing Resources.

Kadoya, Y., \& Khan, M. (2017). Explaining financial literacy in Japan: New evidence using financial knowledge, behavior, and attitude. Behavior, and Attitude (November 8, 2017).

Kasman, M., Heuberger, B., \& Hammond, R. A. (2018). Recommendations for improving youth financial literacy education. Retrieved from: https://www.brookings.edu/wpcontent/uploads/2018/10/ES_20181001_FinancialLiteracy-Reco mmendati ons.pdf

Lusardi, A., \& Mitchell, O. S. (2013). Older adult debt and financial frailty. Michigan Retirement Research Center Research Paper, (2013-291).

Marsh, B. A. (2006). Examining the personal finance attitudes, behaviors, and knowledge levels of first-year and senior students at Baptist universities in the state of Texas (Doctoral dissertation, Bowling Green State University).

Modigliani, Franco, 1975, "The life-cycle hypothesis of saving twenty years later," in Michael Parkin, ed., Contemporary Issues in Economics, Manchester. Manchester University Press. Pp 2-35

Morgan, P. J., \& Trinh, L. Q. (2019). Determinants and impacts of financial literacy in Cambodia and Viet Nam. Journal of Risk and Financial Management, 12(1), 19.

OECD (2014), "PISA 2012 technical background", in OECD (Ed.), PISA 2012 Results: Students and Money: Financial Literacy Skills for the 21st Century, Vol. VI, OECD Publishing, Paris, pp. 123-145.

OECD. (2016). PISA 2015 Assessment and Analytical Framework: Science, Reading, Mathematics and Financial Literacy. Paris: PISA.

Rajna, A., Ezat, W. S., Al Junid, S., \& Moshiri, H. (2011). Financial management attitude and practice among the medical practitioners in public and private medical service in Malaysia. International Journal of Business and Management, 6(8), 105.

RinggitPlus. (2020). RinggitPlus Malaysian Financial Literacy Survey 2020 Report. Retrieved from: https://www.fenetwork.my/wp-content/uploads/2020/11/RinggitPlus-Financial-Literacy-Survey-FullReport.pdf

Soroshian, S., \&Teck, T. (2014). Spending behaviour of a case of Asian university students. Asian Social Science, 10(2), 345.

Tezel, Z. (2015). Financial education for children and youth. In Handbook of research on behavioral finance and investment strategies: Decision making in the financial industry (pp. 69-92). IGI Global.

Thomas, B., \& Subhashree, P. (2020). Factors that Influence the Financial Literacy among Engineering Students. Procedia Computer Science, 172, 480-487. 